\title{
The Mistakes of Yesterday, the Hopes of Tomorrow: Prison, Pop Music, and the Prisonaires
}

John M. Dougan

College of William \& Mary - Arts \& Sciences

Follow this and additional works at: https://scholarworks.wm.edu/etd

Part of the American Studies Commons, Criminology Commons, and the Music Commons

\section{Recommended Citation}

Dougan, John M., "The Mistakes of Yesterday, the Hopes of Tomorrow: Prison, Pop Music, and the Prisonaires" (1997). Dissertations, Theses, and Masters Projects. Paper 1539626085.

https://dx.doi.org/doi:10.21220/s2-v4cd-kb74

This Thesis is brought to you for free and open access by the Theses, Dissertations, \& Master Projects at W\&M ScholarWorks. It has been accepted for inclusion in Dissertations, Theses, and Masters Projects by an authorized administrator of W\&M ScholarWorks. For more information, please contact scholarworks@wm.edu. 
THE MISTAKES OF YESTERDAY, THE HOPES OF TOMORROW:

PRISON, POP MUSIC, AND THE PRISONAIRES

\author{
A Thesis \\ Presented to
}

The Faculty of the Department of American Studies

The College of William and Mary in Virginia

In Partial Fulfillment

Of the Requirements for the Degree of

Master of Arts

by

John Dougan

1997 


\section{APPROVAL SHEET}

This thesis is submitted in partial fulfillment of the requirements for the degree of

-

Master of Arts

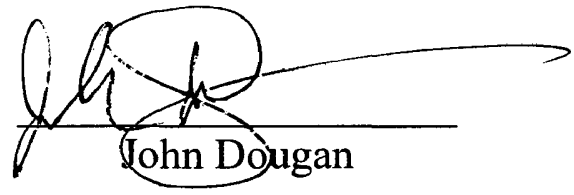

Approved, April 1997

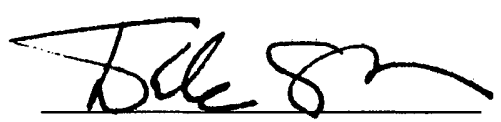

Dale Cockrell

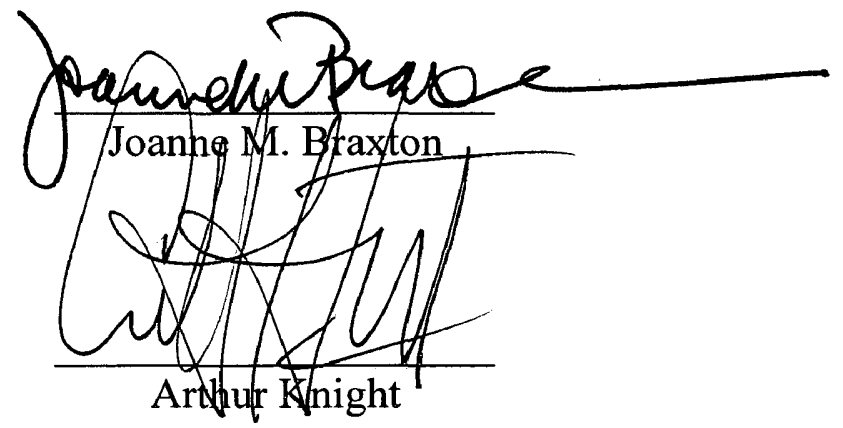

ii. 


\section{TABLE OF CONTENTS}

Page

ACKNOWLEDGEMENTS

iv.

ABSTRACT

V.

INTRODUCTION

2

CHAPTER I. THE CITY

4

CHAPTER II. PRISON AND THE PRISONAIRES

CHAPTER III. THE MAKING AND REMAKING OF MEANING

32

CHAPTER IV. CONCLUSION

45

BIBLIOGRAPHY

48

iii. 


\section{ACKNOWLEDGMENTS}

The fingerprints of many people are on this document, but none more important than those of Professor Dale Cockrell. From the first day we discussed this project his enthusiasm never waned. He provided much of the intellectual framework for the thesis as well as encouraged me to think longer and harder about music (and noise) in ways I never had before. There are precious few scholars and mentors so generous.

Professor Arthur Knight took over the advisory reigns after Dale's departure and offered a careful and insightful analysis. Without the benefit of his nuanced understanding of the underlying issues in the music of the Prisonaires I would probably still be flailing away. Professor Joanne Braxton brought to the table not only her considerable skills as a writer and critic, but her unique ability to theorize through the subject matter challenging me intellectually as she has since the day I met her.

My fellow grad students Jennifer Luff and Wendy Gonaver heard much more about the Prisonaires (and Jacques Attali) than they probably wanted to, but they never complained (at least not to my face) and read parts of the thesis offering advice, support, and fresh ideas. For this and their friendship I am ever thankful.

I was extremely fortunate to benefit from the generosity of writers I've long admired who took an interest in this project: Peter Guralnick was in the middle of finishing a book, yet still took time to read sections of the thesis and open up his research files to me. Rip Lhamon, also finishing a book, contributed his always valuable thoughts and criticism. Bob Oermann hipped me to the music of black Nashville, and Colin Escott gave me the straight dope on Johnny Bragg.

A condensed version of this thesis was presented at the Center for Popular Music at Middle Tennessee State University in 1996 and at the 1997 conference of the Sonneck Society for American Music. I am grateful to both organizations and to all those I met who shared their thoughts and offered advice and encouragement, especially Gena Caponi and Rob Walser. Thanks to Paul Wells, director of the Center for Popular Music, to Cass Paley for providing me with the remarkable interview with Johnny Bragg, and James Edwards for being a gracious man and wonderful storyteller.

Finally, my wife Carol Smith lived with this project too and has listened to "Just Walkin' in the Rain" more times than she cares to remember. And while it is impossible to articulate all that she meant to this project, I can say without a doubt that she made the single most important contribution -- the birth of our son Eamon. His arrival slowed down the writing process, but in the most extraordinary and life-affirming way. 


\begin{abstract}
Early in the morning of June 1, 1953, five inmates from the Tennessee State Penitentiary in Nashville were transported by bus to Memphis. What may have seemed like a routine prisoner transfer was, in fact, a small yet significant moment in the early history of rock and roll, wherein five African-American men stepped, albeit briefly, from incarceration into stardom. They were the Prisonaires, a rhythm and blues vocal group formed by lead singer, and Nashville native, Johnny Bragg who, though only 27 years of age, had been a penitentiary inmate since his teens. This brief day of "freedom" brought them to Memphis's Sun Studios and it's owner Sam Phillips who, despite his dislike of their smooth, intricate singing, recorded two songs, the first of which, a Bragg composition entitled "Just Walkin' in the Rain," sold in excess of 50,000 copies, becoming one of the better-selling records of Sun's pre-Elvis period. A little more than a year later, the Prisonaires were finished, a result of Phillips's post-Elvis move toward harder, grittier rock and roll, and an increasing public disinterest in their somewhat antiquated vocal style. After their brief success, the Prisonaires were relegated to footnote status in the early history of rock and roll; one of the genre's many odd, interesting stories.

But the story of the Prisonaires, with its image of imprisoned African-American men singing as a means of restoring dignity, and its notion of music as a means of psychic survival, cultural representation, and political resistance, is far more profound and telling than the odd, interesting rock and roll story. This thesis will be primarily concerned with the effects of prison life (and its attendant male-defined community and culture) on popular music's creative process, how popular music's meaning becomes a dissonant (and dissident) voice of resistance and empowerment under the constraints of social incarceration, and how the Prisonaires became paradigmatic of the liberal prison reform policies of Tennessee State Penitentiary warden James Edwards.

The Prisonaires career as "pop stars" ended almost as quickly as it began, but the circumstances under which they created and performed music illustrates how popular music can be a method of empowerment even when given shape in the most unlikely and inhospitable of environments. The Prisonaires story, and the music they made, are imbued with a passion that bespeaks the complex negotiation of life as musician, AfricanAmerican, creative artist, and convict.
\end{abstract}


THE MISTAKES OF YESTERDAY, THE HOPES OF TOMORROW:

PRISON, POP MUSIC, AND THE PRISONAIRES 


\section{INTRODUCTION}

Early in the morning of June 1, 1953, five inmates from the Tennessee State Penitentiary in Nashville were transported by bus to Memphis. What may have seemed like a routine prisoner transfer was, in fact, a small yet significant moment in the early history of rock and roll, wherein five African-American men stepped, albeit briefly, from incarceration into stardom. They were the Prisonaires, a rhythm and blues vocal group formed by lead singer Johnny Bragg who, though only 27 years of age, had been a penitentiary inmate since turning 17 . This brief day of "freedom" brought them to Memphis's Sun Studio and its owner Sam Phillips who, despite his dislike of their smooth, intricate, vocalizing, recorded two songs, the first of which was a song co-written by Johnny Bragg and Robert Riley entitled "Just Walkin' in the Rain." Released July 8, 1953 , the record sold in excess of 50,000 copies, becoming one of the better-selling singles of Sun's pre-Elvis period. By the end of 1954, the Prisonaires were finished, a result of Phillips's discovery of Elvis Presley and the label's move toward harder, grittier, (and mostly whiter) rock and roll, and increasing public disinterest in their somewhat antiquated vocal style. After their brief success, the Prisonaires were relegated to footnote status in the early history of rock and roll.

But the story of the Prisonaires, with its images of imprisoned African-American men singing as a means of restoring dignity, and their use of music as a means of psychic survival, cultural representation, and political resistance, is far more profound and telling 
than one of the genre's many odd interesting stories. The Prisonaires career as "pop stars" ended almost as quickly as it began, but the circumstances under which they created and performed music illustrates how popular music can be a method of empowerment when given shape in the most unlikely and inhospitable of environments. The Prisonaires story and the music they made, are imbued with a passion that bespeaks the complex negotiation of life as musician, African-American, creative artist, and convict. 


\section{CHAPTER I: THE CITY}

To be a poor man is hard, but to be a poor race in a land of dollars is the very bottom of hardship.

I've got the blues

-- W.E.B. Du Bois

Those Nashville blues

-- The Louvin Brothers, "Nashville Blues"

Eighteen-eighty was a year of celebration in Nashville. The city was 100 years old and poised on the brink of its first significant period of rapid economic and industrial growth, a period that would last until 1915 and cement its status as a thriving, modern southern city. This postbellum modernist impulse was the result of the 1880 Centennial's reflection of the commitment of Nashvillians to juxtapose a "sincere reverence for southern traditions with a buoyant vision of the city's place in a New South eager to join the national march of progress." 1 The one-hundred-gun salute that signaled the Centennial's opening on April 24 also announced the start of urban expansion that would see this city grow from a multiracial, multiethnic cluster of rich and poor numbering just over 43,000 , to a modern city of over 100,000 by 1915 with, as Nashville historian Don Doyle notes, "clearly defined residential and commercial zones with neighborhoods segregated by race, ethnicity, and social class far more than had been possible before." The modern Nashville now had electric trolley transportation that made suburban living accessible to both its growing white and black middle-class populations. As was

1. Don Doyle, Nashville in the New South 1880-1930 (Knoxville, University of Tennessee Press, 1985), 23. 
happening in many other medium-size cities at this time, rapid growth and its attendant patchwork of neighborhoods was turning Nashville into a city divided by race,ethnicity,and class -- a city caught in the paradox of increasing community

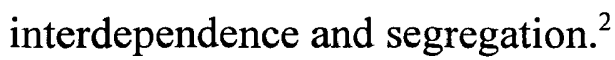

In the post-Reconstruction era Nashville experienced a steady stream of black migration attracted to the city's boom economy and industrial base of slaughterhouses, flour mills, fertilizer plants, lumber mills, and iron foundries. African-Americans were rejecting rural sharecropping and tenant farming for higher paying jobs as unskilled and semi-skilled factory workers, day laborers, and domestic servants. For this population, which by 1880 was nearly 40 percent of the city's total population, Nashville promised economic security, relative freedom, and the restoration of dignity. However, most black workers ended up in what were termed "Negro jobs," a euphemism that for women meant domestic work, and for men any type of mill or factory work too dangerous or low paying for whites. ${ }^{3}$

The relative prosperity offered by Nashville's industrial infrastructure, and the rise in the city's black population, led to a worsening of relations between the city's blacks and whites. Working-class whites, threatened by the increased competition for jobs and fearful that increased participation by blacks would lead to significantly lower wages, actively pursued political attempts at black disenfranchisement. Using racist sentiments to frame their ideology, the Democrats defeated twelve-time Republican mayor, Thomas

2. Doyle, Nashville in the New South, 23.

3. Don Doyle, Nashville Since the 1920s (Knoxville: University of Tennessee Press, 1985), 30. 
Kercheval in 1883, interrupting a 15-year period of Republican domination. During this time, blacks were elected to the city council and Kercheval, a classic party boss who ran the city's political machine, traded political favors to black ward leaders for votes. With a white population politically motivated by racist-inspired fears of possible economic displacement, miscegenation, and the spread of communicable diseases, Kercheval's defeat signaled that, as it entered the twentieth century, race relations in Nashville would never be the same. And with the construction of the city's mass transit system in the 1890 s, suburbanization and neighborhood segregation were, to those who could afford to leave the city's urban core, only a ten-cent trolley ride away. ${ }^{4}$

Then (as now) much of Nashville's black population was concentrated on the city's north side. Smaller, poorer black neighborhoods were scattered within the city's industrial core, many of them little more than slums. Opportunistic landlords quickly built generic unpainted frame houses, which usually consisted of two or three rooms and no indoor plumbing. With rents averaging $\$ 10-\$ 15$ per month (as of 1920 ), for newly arrived black families this was the only affordable housing in the city. Still, the rent absorbed much of the family's earned income forcing them to take in boarders, as well as raise vegetables and small farm animals. According to a 1930 study by John Paul McConnell, more than three quarters of the city's black renters lived in this fashion. Nashville's growing black working class lived in cramped, unhealthy, desperate places with metaphorically resonant hardscrabble names that sounded lifted from dime novels: Black Bottom, Mud Flats, Crappy Shoot, and most notoriously, Hell's Half Acre. ${ }^{5}$

4. Doyle, Nashville in the New South 1880-1930, 89-90.

5. Doyle, Nashville Since the 1920s, 45-48. 
During the 1920s, Hell's Half Acre, located in the shadow of the capital building, became Nashville's Harlem, offering to its mostly black denizens a tantalizingly illicit triumvirate of gambling, bootleg liquor, and prostitution. Its heart was Cedar Street (now Charlotte Avenue) between Fourth and Fifth Avenues. Lined with clubs like Dave's Place, the Silver Streak, and the Blackhawk Restaurant, these semi-upscale establishments were where Cedar Street's uptown rulers and entrepreneurs met for evenings of jazz, whiskey, and women. North of Cedar was the seedier and more licentious Crawford Street, Nashville's red-light district. For those seeking a short-term interracial tryst it meant negotiating prices with Crawford Street's infamous (and numerous) black female brothel owners: women like Ruth "Queen of the Hill" Vance, "Lady" Frank, and "Swamp Lily" Wilson, the latter best known for her dubious personal hygiene and vicious attack dogs. The city's putative center for saturnalia, Crawford Street had it all: clip joints, live sex shows, gay and lesbian nightclubs, and easy and affordable access to marijuana, cocaine, and heroin. ${ }^{6}$

Despite the danger, intrigue and funky romanticism of Cedar and Crawford Streets, Nashville's black working class, especially its children, faced a bleak future. From the turn of the century through the Depression, the black mortality rate in working class communities was nearly twice that of whites. Social health surveyors at the time blamed this high black mortality rate in explicitly racialized terms as "a social maladjustment to the urban environment or that the negro is unable to meet urban competition for the right to live. ${ }^{17}$ Excessive economic pressure forced generation after

6. Doyle, Nashville Since the 1920s, 42-44.

7. Doyle, Nashville in the New South 1880-1930, 109. 
generation of Nashville's African-American youth from the classroom and into premature adulthood. During this period, black boys and girls left school in large numbers, and at increasingly younger ages, to work as houseboys, newsboys, and (the girls) as laundresses, earning less than half of what could be earned in a factory. City surveys of the period confirm this: In $1929,1,800$ black children started first grade, but of this group only 52 graduated from high school. ${ }^{8}$

For black adolescent male high school dropouts, petty theft was the most expedient means of supplementing the hand-to-mouth wages earned as newsboys, and delinquency among young black males increased dramatically as youth gangs became surrogate families. Doyle notes that delinquents came from families broken by divorce, desertion, or death and the youth gang supplied a kind of social organization otherwise thought to be lacking in the slums. ${ }^{9}$ In 1926, John Gordon Gay, a graduate student at Vanderbilt University, personalized this scenario in his study of Henry Emerson, a 14year-old black boy who lived with his family in the city's cramped, poverty-stricken Capital Hill area. Gay's thesis was an urban sociological study prototypical in its representation of the increasing socioeconomic desperation faced by Nashville's black underclass; he found that Henry's mother supported her two children and an elderly women who provided live-in child care, on less than $\$ 40$ per month earned working 75 hours a week as a domestic for a wealthy, white suburban family.

Given this bleak scenario it is not surprising to discover that concomitant with this

8. Doyle, Nashville Since the 1920s, 49.

9. Ibid., 52. 
rise in juvenile crime was an increase in juvenile incarceration. According to the Tennessee Board of Prison Commissioners in the early twentieth century the percentage of prisoners under the age of 20 was "consistently around one-third of the total prison population." The report further notes that of this under- 20 population nearly 80 percent was black. As for offenders under the age of 18 , a 1910 report on the 3,743 incoming inmates into the state's workhouses and jails shows a juvenile population of 577 , a little more than 15 percent. Of these 577 inmates 83 percent were black. Randall Shelden who has studied changes in the Tennessee penal system in the early twentieth century notes that although laws were passed to limit the number of juveniles sentenced to adult prisons, "large numbers of black youths were still subject to this form of punishment, even after the opening of the juvenile court in 1910." 10

One of these black youths was Johnny Bragg. He was born into this modern Nashville on January 18, 1926, the same year Henry Emerson's life became paradigmatic of Nashville's black underclass, and grew up in North Nashville on Herman street, near Jefferson, in the heart of the city's black section. ${ }^{11}$ While Bragg is often evasive and contradictory about specific events in his early childhood, one constant, perhaps the constant in his life was music. Raised on gospel, Bragg's vocal skills were developed and honed in the city's black churches and on its streets and back alleys. By age six he was

10. Randall G. Shelden, "From Slave to Caste Society: Penal Changes in Tennessee, 1830-1915," Tennessee Historical Quarterly 38, no. 4 (1990): 465.

11. Colin Escott, liner booklet essay for the Prisonaires, Just Walkin' in the Rain, reissued as Bear Family BCD 15523, compact disc. According to Escott, Tennessee state prison records show Bragg's birth date as January 18, 1926. Bragg however claims that this was in fact his brother's birthday, a date he used because the city had no trace of his actual birth date, which he says was May 5, 1929 
already a skillful singer and quickly assumed the role of lead singer in a number of makeshift vocal groups consisting of children from the neighborhood, children he called, "little young street guys." ${ }^{12}$ The material leaned heavily on gospel ("Precious Lord" was a particular audience favorite), but pop music also figured into this street corner sound, the result of Bragg spending countless hours singing along with his grandmother's player piano.

Despite his considerable talent, Johnny Bragg's life, not unlike that of many African-American boys growing up in Depression-era Nashville, was one of hard luck, violence, poverty, and tough breaks. He left school at age 11 and turned to petty theft, mostly house burglaries, as a means of survival. Bragg describes himself as a "bad boy. . .didn't take no shit from nobody back then," and it was not many years before this immensely talented, North Nashville bad boy, found himself part of the inmate population at the Tennessee State Penitentiary. ${ }^{13}$

The conviction was on six counts of rape, the sentence for 99 years. According to state prison records Johnny Bragg was seventeen (Bragg himself claims he was only fourteen) when he entered the Tennessee State Penitentiary in Nashville in 1943. Bragg maintains to this day it was a frame up, the result of an angry girlfriend's accusation and racist Nashville police who saw him as a convenient fall guy to take the rap for five other unsolved sexual assaults, one of which involved a white woman.' Bragg alleges that he

12. Johnny Bragg, interview by, Don Hildebrand and Barry Alphonso, September 25, 1996, transcript, Cassell Productions, Thousand Oaks, Ca.

13. Ibid. 
discovered an affair between his then-girlfriend Jenny Price and another friend he refers to only as Chester. A confrontation between Bragg and Chester led to a fight that ended with Price going to the police claiming that Bragg had raped her. ${ }^{14}$ Bragg's court appointed lawyer encouraged him not to testify, assuring him and his father that if allowed to handle the case his way, Bragg would serve no more than nine months in jail. Although the details remain at best sketchy and difficult to verify, Bragg claims that the conviction on the six counts and the severe sentence meted out was the result of a conspiracy organized by a detective he thinks was named Raybe. The detective allegedly coerced the accusers and witnesses to identify Bragg as the perpetrator in all six cases. "When I got out of prison," Bragg notes, "one lady told me, one of the chief witnesses, she said that they talked us into lyin' on you, said, 'we know that we made a mistake'."15

But it was while in prison that Johnny Bragg became famous. After a falling out with the gospel quintet he formed soon after his incarceration, Bragg took two of its singers, Ed Thurman and William Stewart, each of whom were doing 99 years for murder, hooked up with recent penitentiary arrivals John Drue (three years for larceny), and Marcel Sanders (one-to-five for involuntary manslaughter) and formed the

14. Bragg interview, 15-17. Bragg's story of the circumstances leading up to his rape arrest contains many gaps and missing details. For example, the situation involving Jenny Price's report of Bragg's attempted rape to the police is never addressed in detail. Why were her allegations enough to prompt allegedly racist white Nashville policemen to act quickly and arrest Bragg? If Nashville's white policemen were racist, why was Jenny Price's report -- the report of a teenage black girl -- taken so seriously? Perhaps if Bragg had had a long history as a major crime figure, Price's complaint would have been reason enough to have him arrested. But Bragg's criminal history up to the time of his arrest involves little more than petty theft. Many questions regarding Bragg's arrest remain and are deserving of further investigation.

15. Ibid., 21. Although the incidents surrounding Bragg's arrest are unclear, what is certain is that he was not given the best legal representation, nor was he judged by a jury of his peers. As he notes, "We didn't have no black people in the jury in those days, no black people, just nothing but white people. If a white person didn't like you your ass was grass." 
Prisonaires, an r\&b harmony group whose lone hit record was recorded by Sam Phillips in 1953 for Sun Records, the silky smooth, "Just Walkin' in the Rain." Framed by William Stewart's elegant guitar playing, Bragg's singing is stunning -- a warm, throaty croon that breaks into a swooping falsetto in the final verse, made even more compelling by his impeccable phrasing. It is a subtle, seductive performance on a par with those of seminal $r \& b$ singers of the era like Bill Kenny of the Ink Spots (Bragg's idol) and Sonny Til of the Orioles. And while Bragg and the Prisonaires sang the original, definitive version of "Just Walkin' in the Rain," it became more widely known as hit for another crooner, the over-emoting Johnnie Ray, who sold over one million copies of the song in 1956.

Within weeks after the song's release the Prisonaires were receiving nearly twodozen fan letters a day, were featured in the pages of the Memphis Commercial Appeal and Ebony magazine and, with the help of warden James Edwards and Governor Frank Clement, made numerous personal appearances throughout Tennessee. Jud Phillips, Sam's younger brother and the newest member of Sun Records' marketing and promotion department, could barely contain his enthusiasm after his initial meeting with the group. In a memo to Sam, Jud wrote: "They make me think of a bunch of baby birds. They are fine boys all of them. I get great joy out of helping people like that ... I know you do too."16

The success of "Just Walkin' in the Rain" played a small, yet significant role in the history of rock and roll as the song that put Sun Records on the map. Music historian and 16. Escott, 6. 
Elvis Presley biographer Peter Guralnick notes, "Just Walkin' in the Rain," which sold in excess of 50,000 copies, likely was the record that captured the attention of a young Elvis as he read about the studio, the record label, and Sam Phillips, a man who had "staked his reputation on a recording by an unknown singing group and a song whose plaintive notes Elvis heard reverberating over and over again in his mind and in his memory and on the air." ${ }^{17}$ So indelible was the impression that Bragg's singing made on Elvis that, after his discharge from the Army in 1961, he visited Bragg in prison (Bragg was back inside on a parole violation) and offered to pay his legal bills. Bragg declined, telling Elvis he would be out in a matter of months. He was released seven years later. ${ }^{18}$

For all of the tantalizing contiguity and occasional intersection between the careers of Elvis and the Prisonaires, the group's story is one wherein fact and fiction blur, much of the blurring the result of Bragg's (the group's lone surviving member) selfmythologyzing. Bragg's recollections often place him in the company of the famous, or at the center of seminal musical events, the recurring theme being that in each case the celebrity in question recognizes and lauds Bragg's talents as a singer or songwriter. He remembers sneaking into the Silver Streak Club (Nashville's version of Harlem's Cotton Club) as a nine-year-old, running from dressing room to dressing room in the hope of meeting one of the entertainers. One particular evening, after being chased away by an annoyed Cab Calloway, Bragg went into Billie Holiday's dressing room and boldly announced to her that he wanted to be a singer. He remembers: "She said let me hear

17. Peter Guralnick, Last Train to Memphis: The Rise of Elvis Presley (New York:Little Brown, 1994), 57. 18. Escott, 19. 
something, I said I could sing 'A Tisket A Tasket', she said 'You can sing!' I'll never forget that, she was a good lady." 19

In the most frequently repeated of his stories, Bragg claims that Elvis was in Sun studios during the marathon recording session of June 1, 1953 that produced "Just Walkin' in the Rain," a "fact" that contravenes every historical account of Elvis's first appearance at Sun. According to Bragg:

"I helped Elvis get his break. Elvis used to slip into the studio and Sam Phillips got mad. I was having problems pronouncing the words, I could hit the notes, but my diction was bad. And this little ol' guy comes out of nowhere -- raggedy blue jeans, dust all over his face, 'I can help you with them words' -- Sam Phillips pitched a ball, 'Boy I've told you to stay outa here ... we got all these nigger convicts down here, something'll happen if they call us down.' One thing led to another and I said, 'Mr. Phillips give him a chance,' and that's how Elvis got his break."20

What is important (and ultimately erroneous) about this story is that it places Elvis inside Sun Studios on June 1, 1953. One can also infer from Bragg's story, specifically in the repartee between the young Elvis and the irritated Sam Phillips, that Elvis had been hanging around Sun for a while prior to this alleged incident. In Last Train to Memphis, Peter Guralnick, based on interviews with Marion Keisker, the first person at Sun to have any contact with Elvis, notes that he did not walk through the front doors of 706 Union Avenue until August, 1953. Colin Escott, in Good Rockin' Tonight, repeats the above

19. Bragg interview, 15.

20. Ibid., 6 . 
Bragg story adding that Sam Phillips didn't extend an invitation to Elvis to record at Sun until May $1954 .{ }^{21}$ What is likely is that Bragg simply mixed up the dates.

In remythologyzing his career, Johnny Bragg does so not in bitterness that his greatness went unnoticed, or that those performers who "made it," did so lacking talent equal to his. Instead, this repositioning of his role in the history of rock and roll is a means of creating agency and visibility. In an effort to encourage a more careful consideration of his (and the Prisonaires) career, Bragg's emphasis on his brushes with the famous and soon-to-be-famous is an attempt to suggest an historical approach that goes beyond the predictable irony of Bragg and the Prisonaires as simply criminals and pop musicians. Johnny Bragg may have stepped in and out of rock and roll history briefly, making his greatest impact while isolated from the music industry and society in general, but he is quick to note that this in no way precludes his leaving a mark on popular music. His stories (be they real or fictitious) are important, for they, like the music he made with the Prisonaires, are attempts to restore the dignity and respect he feels he has been denied.

That the Prisonaires achieved fame as a novelty act and were finished as a group a little more than a year after their first recording session has consigned them to the margins of rock and roll history. Yet it is because of their being overlooked and under analyzed, and Bragg's ever-shifting historical revisionism and propensity for mythologization, that the story of the Prisonaires is a significant one. It is a story wherein the making of meaning is an ongoing process of negotiation, not just between the artist and the music industry, but also the fluid social organization of the city, and the consolidated and rigid total institution of prison. The music of the Prisonaires, created 
under the constraints of social incarceration utilizes, to paraphrase Eugene Genovese, a tradition of indirection necessary for survival under conditions of domination manifested as a way of life. As unlikely pop celebrities making music in an inhospitable environment, the Prisonaires tested the flexible limits of possibility wherein a means of cultural expression, born in isolation, is "freed" (as are they, temporarily) by its use as a commodified form. 


\title{
CHAPTER II: PRISON AND THE PRISONAIRES
}

\author{
Then I heard the jailer say, "Hello! Prisoners all fall in line." \\ --Leroy Carr, "11.29 Blues"
}

The Tennessee State Penitentiary, the state's first prison, opened in Nashville in 1831. Modeled on prisons in New York and Pennsylvania, the penitentiary employed the Auburn system, a common method of nineteenth-century prison management. The system was developed by Louis Dwight of the Boston Prison Discipline Society whose primary concerns were saving the souls of wayward men and the development of prison industries that would realize profit for the prison through convict labor. According to Michel Foucault, the Auburn system "was a clear reference to a monastic model; a reference, too, to the discipline of the workshop."1 The fundamental brilliance of the system, according to its architects and supporters, was that it was in fact a duplication of society. As a result, the system, to Foucault, was a microcosm wherein "individuals are isolated in their moral existence, but in which they come together in a strict hierarchical framework, with no lateral relation, communication being possible only in a vertical direction." Therefore incarceration under the Auburn system meant that prisoners shared space only during work time and meal hours, and then in absolute silence. Prisoners spoke only to guards, only in a low voice, and only if they received permission. ${ }^{2}$

The use of labor as a means of rehabilitation through moral inculcation was as

1. Michel Foucault, Discipline and Punish: The Birth of the Prison (New York: Vantage, 1979), 238.

2. Ibid. 
important to the success of the Auburn system as was its implementation of a monastic hierarchy. Penal labor was the vehicle by which violent prisoners learned habit, order and obedience, and in doing so generated enough income (or so it was hoped) for the prison's ultimate goal, economic self-sufficiency. Most nineteenth-century penal theorists agreed that the application of one's physical and mental capacities in a routinized, structured fashion reduced violent tendencies and had an overall calming effect on prisoners. Foucault quotes the penologist Leon Faucher who, writing in 1838, emphatically cut to the heart of the Auburn system: "work is the providence of modern peoples; it replaces morality...work must be the religion of prisons. ${ }^{13}$

Foucault's analysis of this incarcerated labor force concluded that penal labor was not the panacea supporters of the Auburn system claimed; prisons, by and large, did not produce ex-convicts with transferable skills for an increasingly industrialized marketplace. Instead, penal labor was in fact the creation of power relationships wherein the newly "skilled" convict-workers were dominated by the prison/workshop's goal of producing individuals acclimated to the demands of industrial society. The once-violent criminal, his idle moments now filled with mind-numbing, repetitive work, is not taught skills to enhance possible future employment but rather is made docile through the process of work and the payment of wages. Remuneration for labor (admittedly much lower for convicts than those on the outside) now defines the conditions of his existence. Thus, the payment of wages and attendant feelings of accomplishment resulting from 
earning one's way produces the "love and habit" of work in the convict-worker. "The wages of penal labor do not reward production; they function as a motive and a measure of individual transformation: it is a legal fiction since it does not represent the 'free' granting of labour power, but an artifice that is presumed to be effective in the techniques of correction. ${ }^{14}$ In his analysis Foucault does not consider race and how an increasing prison population made up primarily of a minority community might have an impact upon the employment of the Auburn system and its attendant ideology. During the antebellum period the Tennessee State Penitentiary's population was predominantly white; AfricanAmericans were not sent to prison in large numbers, their criminal offense (alleged or otherwise) were dealt with locally, swiftly, and very often, brutally. Randall Shelden notes that after the Civil War, freed blacks represented a threat to Southern white supremacy and the local enforcement of racist-inspired jurisprudence was quickly codified by the state in an attempt by the white population to systematically reestablish their dominance. ${ }^{5}$ H. Bruce Franklin echoes this: "Central to this historical redefinition of the role of black people was an ideological redefinition of them. No longer were they just a subhuman race; now they were to be thought of as a race of criminals." ${ }^{16}$ With postbellum laws rewritten in an effort to criminalize many forms of black behavior, the racial shift in the Tennessee prison population was dramatic. In 1865, blacks made up 33 percent of the inmate population at the State Penitentiary; by 1867 it had increased to

4. Ibid., 248.

5. Shelden, "From Slave Society to Caste Society," 465.

6. H. Bruce Franklin, The Victim as Criminal and Artist (New York: Oxford University Press, 1978), 101. 
nearly 60 percent and by 1869 to 64 percent, and it averaged 60 percent well into the twentieth century. These significant increases in the black prison population came in stark contrast to the black population of the entire state which was rarely higher than 20 percent. $^{7}$

With this change in the racial makeup of the prison population came a shift in the state's attitude toward the employment of the Auburn system. While much of the system's infrastructure remained (e.g., strict hierarchical framework, labor as a way of eliminating violent behavior) the system itself became racialized. The goal of teaching prisoners habit, order, and obedience remained, but replacing the idea of inculcating inmates with the love and habit of work, was the economic bonanza to be made through the convict leasing system.

In Tennessee, the introduction of convict leasing directly corresponded to the increase in the black prison population, and as Randall Shelden notes, "more than any other innovation of the time, [convict leasing] helped support economic recovery, the maintenance of white dominance, and the conquest of Northern capitalism." ${ }^{8}$ The convict lease system was for all intents and purposes an extension of Louis Dwight's original Auburn model in that it created profit for the prison by leasing convicts out rather than bringing the work inside. As described by Fletcher Melvin Green, the state leased to the highest bidder all or part of the convict population for a fixed sum; the lessee would meet all the expenses of management, including housing, protection, food, clothing, and

7. Shelden, 465.

8. Ibid. 
guarding, connected with the employment of the prisoners. The lessee was also given complete authority over the control and punishment of the prisoners, relieving the state of all obligation and responsibility while exposing the prisoners to, potentially, more violent and, often, life-threatening situations than they faced in prison. Most important, however, all payments by the lessee were clear profits to the state. ${ }^{9}$

By the 1870s Tennessee's.inmate population became the principal workers on a $\$ 14$ million project to rebuild the state's railroads. Coal mining companies regularly employed leased convict labor, and in a stunning move in 1884, the Tennessee Coal, Iron and Railway Corporation leased the entire prison population in Nashville. It was a bleak existence, and for most convicts leased out, the only relief was escape or, more frequently, death. Prison historian Blake McKelvey, writing in 1936, noted that as a result of the convict lease system, thousands of African-Americans awoke from "rosy dreams of freedom and forty acres and a mule to find themselves shackled to the task of rebuilding the wealth of the South in hopeless penal slavery."10

By the time Johnny Bragg entered the Tennessee State Penitentiary in 1943, the prison had relied upon the Auburn system for over a century. Convict leasing, its intense brutality now a matter of public record, had been abolished in most southern states by the mid-1930s and prison work for profit returned to the contract model that allowed businesses to use convicts as a poorly paid, temporary labor force. But while the brutality

9. Fletcher Melvin Green, "Some Aspects of the Convict Lease System in the Southern States," from Democracy in the Old South, ed. J. Issac Copeland (Nashville: Vanderbilt University Press, 1969) 274.

10. Blake McKelvey, American Prisons (Montclair N.J., 1968) 180. 
of convict leasing had been abolished in theory, it was an ongoing reality within the Penitentiary walls, especially during the lengthy tenure of warden Glenn Swafford. Swafford, a former prison guard who had worked his way through the system, became warden in 1915, the start of a career in prison administration that would last nearly forty years and see him serve under 11 governors. ${ }^{11}$ A strict disciplinarian not averse to using violence and fear as a means of controlling the prison population, Swafford employed a severe permutation of the Auburn model that retained little if any of Louis Dwight's salvation-minded paradigm. It was not long before the Penitentiary became more widely known as "Swafford's Graveyard."12

Swafford's iron-fisted rule ended abruptly with the election of Governor Frank Clement in 1953. Clement, part of a new breed of progressive southern democrats, announced that the new warden of the penitentiary would be his childhood friend, James Edwards. Edwards's credentials seemed to indicate that he was the right man for the job: marine combat veteran, a stint with the military police, executive officer in the Tennessee National Guard's police battalion and, most importantly, a firm believer in the Auburn system of prison management, especially the concept of prison self-sufficiency. Although Swafford was surprised (and somewhat bitter) at his unceremonious dismissal, everything about James Edwards's resume indicated that, at age 36, he would be a younger, less demagogic version of Swafford: a by-the-book, no-nonsense, law-and- order warden. The truth was that James Edwards was the antithesis of Glenn Swafford. A progressive,

11. Elmer Hinton, "Edwards to Use MP Experience," Nashville Tennessean, January 11, 1953.

12. Author unknown, "Warden Uses Prisonaires as Example of Humane Policy," Ebony, November 1953. 
reform-minded prison administrator Edwards believed that people were sent to prison as punishment, not for punishment. His main goal as warden (in keeping with the Auburn model) was to provide inmates with work skills necessary to facilitate their return into non-prison society. As far as Edwards was concerned this goal was simple and obvious, its benefits -- lower taxes and reduced recidivism -- providing an assured rebuttal to the criticism of those who felt that this was nothing less than coddling society's undesirables.

In a speech given to the Nashville Exchange Club six months after his hiring, Edwards publicly decried the Tennessee prison system as being "fifty years behind the times." Calling prison conditions deplorable, he noted that the facilities themselves had become little more than "receiving stations" wherein inmates did their time and were released with "a bus ticket and a dollar-and-a-half to get to their homes." He then detailed his efforts (all done with Governor Clement's blessing) to improve prison living conditions, provide inmates with work-skills training, increase the prison's outside contract work (a critical factor in skills training), and improve the quality and amount of food served to inmates. In closing, Edwards somewhat provocatively suggested that prisoners "need a job when they leave, but they also need more than that." Although he wasn't specific as to what the latter might be, it's clear that as far as he was concerned, prison reform was an ongoing process that required a commitment from the outside world to continue the efforts begun in prison. Dramatically driving his point home, Edwards's speech concluded with the first public performance by the then nameless Prisonaires, 
referred to in the article as the penitentiary's "prisoner quintet." As described in the article, "This group of Negro Singers, which has already recorded several songs, was loudly applauded by the civic club members." 13

Radical as it was for its time, Edwards considered his liberal prison reform policy as simple common sense, and his reputation as a maverick progressive somewhat overstated..$^{14}$ As much as he represented a near total break with Glenn Swafford's "graveyard" mentality, he still believed in a by-the-book approach to prison management. But unlike Swafford, Edwards was a hands-on warden, a micromanager who believed in being friendly and accessible to the inmate population, yet tough and inflexible when necessary. ${ }^{15}$ "I felt that part of my purpose as warden was to get in touch with the prisoners, treat them just, and keep everything above board. I was accessible to the inmates, but I never got too close. Maintaining that separation between warden and inmate was important." ${ }^{16}$ From Johnny Bragg's point of view, Edwards fortuitous arrival and his importance to the Prisonaires story cannot be overstated: "They [Clement and

13. Author unknown, "Warden Edwards Cites Prison Improvements," Nashville Banner, June 17, 1953.

14. James Edwards interview by author, May 18, 1996. Edwards tends to downplay his role as a progressive warden: "I never really considered myself a maverick, but at the time I became warden any step would have been progressive."

15. Author unknown, "Warden Edwards Tightens Control on His Charges," Nashville Banner, March 18, 1953. Edwards's toughness was tested only a few months after becoming warden. A large group of prisoners protested Edwards's revoking of keys to the master locks controlling a tier of cells. The keys had, surprisingly, been given to certain trusted prisoners who functioned as inmate-turnkeys during Glenn Swafford's regime. The system was riddled with abuse, nearly any inmate who wanted could get a set of keys allowing them easy access from cell block to cell block. The protesting inmates stayed in the prison's central yard and refused to return to their cells. Edwards locked all the cell entrances and told the prisoners they were welcome to stay in the yard but should plan to do so all night. After forcing them to stand in the cold rain for a few hours, Edwards flooded the yard with searchlights. The prisoners quickly returned to their cells.

16. Edwards interview. 
Edwards] were really interested in the rehabilitation program. . .they were backing us 100 percent. Now you had a lot of guards back there that didn't like the idea. . .but the most important thing was the inmates -- see if the inmates didn't like it you couldn't make it. . .if the inmates didn't like it they'd kill you." As for Edwards himself, Bragg believes "God sent him along. He did almost the impossible."

At the time Edwards assumed control of the penitentiary one-third of its prisoners (approximately 400) were under the age of 20, and of that part of the prison population nearly 80 percent was black. In the mid-50s South, segregation was as common inside prison walls as it was outside. There were white and black wings, with the dining rooms and sleeping areas completely segregated, but Edwards saw to it that all work details, athletic teams, and common areas were integrated. Audiences for the musical performances and professional wrestling matches that were frequently booked were also integrated. As Edwards describes it, problems within the prison stemmed more from the small percentage of criminals, black and white, who either attempted to disrupt the normal workings of the prison, or tried to escape. Even after the success of the Prisonaires, he notes that there was little if any racial hostility exhibited by white inmates toward the group due to their "celebrity" status. ${ }^{18}$ Bragg, however, remembers a more violent reality. Although he does not specify whether the threats came from white or black inmates he does recall: "A lot of guards didn't like the idea that the niggers were going out singing. . .a lot of people wanted to kill us. . fellow prisoners and the guards

17. Bragg interview, 43.

18. Edwards interview. 
wanted to set it up, the guards set up for a lot of people to get killed in those days. They wanted Johnny Bragg bad, they wanted to kill that nigger." ${ }^{19}$

Edwards became aware of the Prisonaires a few months after becoming warden. They were somewhat legendary for their singing, and Bragg especially for his unorthodox vocal training, which consisted of singing for extended periods with a bucket over his head. Initially, it was Joe Calloway, from Nashville radio station WSIX, who heard the Prisonaires while at the penitentiary preparing a newscast and suggested to Edwards that they perform on Nashville's black radio station WSOK. At about the same time music publisher Red Wortham had gone to the prison to buy songs from Bragg. According to Colin Escott, the prison "was a fertile source of new songs, and many Grand Ole Opry stars paid regular visits to buy material from black and white inmates." Bragg, who had been writing songs from the day he was incarcerated, also claims to have sold numerous songs to country performers who visited him at the prison. "The word got out," Bragg recalls, "that this little ol' nigger in the penitentiary can write anything you want him to write. . he's a genius. I couldn't even pronounce the word genius. I thought they were calling me a genie, I'm no genie, I'm just a man like everybody else." And while it is probable that Bragg sold songs or song ideas to the likes of Ernest Tubb, Roy Acuff, and Little Jimmie Dickens (all of whom performed at the penitentiary), perhaps the most audacious of all of Bragg's claims, one that would necessitate a major rewriting of the

19. Bragg interview, 45. Bragg tells of one nearly successful plot against his life: "They [other inmates] set a trap to knock me off. . .they tried to electrocute me one time, they had it fixed, this room, and I'm getting ready to open the door to go iron my clothes and a guy named Curly knocked my hand out of the way. He said, 'Johnny you're supposed to be dead.' I said, 'What are you talking about?' He picked something up and said, 'Watch this.' He threw it against the doorknob and [Bragg makes sound of an explosion]." 
history of country music, is his assertion that is was he, not Hank Williams who wrote "Your Cheatin' Heart." "I had different versions for every song and four or five different ways to sing them," Bragg says, "'Your Cheatin' Heart' I had two or three different versions. . .Hank Williams and this older white man (here Bragg may be referring to Ernest Tubb) came to listen to the song, and as soon as he heard the song -- he [Williams] wanted it. I sold that song for five dollars, now it's over 200 million. . I was the five dollar man. If you had five dollar you got a hit song."20

Wortham sent a tape of the Prisonaires recorded at WSIX to Jim Bulliet, a major figure in the Nashville independent record business of the 1950s and minority shareholder in Sun Records. Bulliet sent the tape to Sun Records owner Sam Phillips recommending that the Prisonaires be signed. Phillips, unmoved by the group's smooth Ink Spots-style close harmony singing, saw great potential in the group's novelty slant and with Bulliet's help arranged, with Edwards's permission, for the Prisonaires (who were nameless at this point) to be taken from Nashville to Memphis by armed guard to record at Sun studios. In a marathon, 10-hour recording session on June 1, 1953, the group cut just two tracks: "Just Walkin' in the Rain" and "Baby Please." Sixteen days later, the Prisonaires (still without a name) made their debut for the Nashville Exchange Club. A few weeks later, on July 8, "Just Walkin' in The Rain," by the newly christened Prisonaires, was released by Sun. ${ }^{21}$

20. Bragg interview, 32. Escott, Just Walkin' in the Rain, 5. Escott exhibits little skepticism regarding Bragg's alleged contribution to country music, "It is at least possible," he writes, "that Williams bought the genesis of the song from Bragg as he bought other songs that he made uniquely his own." This theory, however, is not repeated in Escott's 1993 Hank Williams biography.

21. Escott, Just Walkin in the Rain, 6. 
Fifty thousand copies later, "Just Walkin' in the Rain" was a hit, albeit a modest hit. For the pleasantly surprised Sam Phillips that was the bottom line, but for James Edwards and Frank Clement, it was a hit single with enormous sociopolitical implications. Newspapers in Nashville and Memphis quickly ran stories on these unlikely pop stars. Ebony magazine devoted three photograph-filled pages to the group, and according to Sam Phillips's brother and record promotion man, Jud Phillips, the Prisonaires were receiving dozens of fan letters every day. It was not long before warden Edwards was regularly approving day passes for the Prisonaires to perform throughout Tennessee. ${ }^{22}$ For Edwards the humanitarian and prison reformer, it was a public relations dream come true. For Frank Clement, the man who had fired Glenn Swafford in favor of Edwards, it was confirmation that he had done the right thing and his unabashed enthusiasm for the Prisonaires reflected this. ${ }^{23}$ "The Prisonaires represent the hopes of tomorrow rather than the mistakes of yesterday, "Clement declared to a reporter for the Memphis Press-Scimitar. "If just one person is led to a better way of life thru (sic) their music our efforts have not been in vain."24 Soon the Prisonaires became regular fixtures at the Governor's mansion performing twice a month for assembled guests, often

22. The money earned from these public appearances, as well as money earned from record sales and songwriting royalties were all managed by the prison. According to James Edwards, "Ten percent of any money earned went into a prison recreation fund. What was left over was banked for them." Bragg tells a somewhat similar story with these discrepancies: the percentage given to the inmates fund was 20 percent; the inmate fund was all his idea; and most of the money banked for them was allegedly stolen by Red Wortham.

23. Edwards interview by author. He notes that the reaction by both the press and public to the Prisonaires was, "mostly positive, we had had baseball and softball teams that often traveled outside the prison so it was not as if this had never happened before."

24. Clark Porteous, "Prison Singers May Find Fame With Record They Made in Memphis," Memphis Press-Scimitar, July 18, 1953. 
chauffeured there by James Edwards's wife, Evelyn. Seizing the moment, the group quickly wrote and recorded a tribute to Frank Clement entitled, "What About Frank Clement (A Mighty, Mighty Man)" which, as Colin Escott rightly notes, had "parole, please" written all over it. The song was not released until $1990 .^{25}$

Clearly, had Glenn Swafford remained warden of the Tennessee State Penitentiary, the story of the Prisonaires would be one of myth and speculation -- the greatest rhythm and blues vocal group you never heard of. Johnny Bragg's "career" as an inmate/musician was almost ten years old by the time James Edwards became an integral part of the story, and it's safe to say that Swafford (who allowed, but never encouraged, the musical inclinations of Bragg and his fellow prisoners) would have found the idea of a group of inmates, two of them convicted murderers, working outside the prison as singers unthinkable. ${ }^{26}$ Edwards and Clement, on the other hand, saw the Prisonaires as the centerpiece of their push for prison reform. Bringing them to perform at the Nashville Exchange Club, allowing them to tour outside the prison, entertaining guests at the Governor's mansion, were all inspired moves indicating the range of opportunities available to inmates through a serious commitment to prison reform.

But the initial success of the Prisonaires is not without its curious and problematic underside. Edwards, who admits to not being knowledgeable about music or having any

25. Escott with Hawkins, Good Rockin' Tonight, 46.

26. According to James Edwards, as unthinkable as letting the Prisonaires "tour" might have been to his predecessor, Glenn Swafford did relax his rules to the extent that the inmates were allowed radios and record players. 
musical ability, was still savvy enough to realize that the smooth, melodic sound of the Prisonaires would be an easy sell to the Exchange Club's all-white audience, an audience comfortable with the stereotype of African-Americans as genetically-encoded entertainers. While Edwards's intentions were undoubtedly honorable, they too reflect a need to reaffirm the prison's institutional discourse. The conduct of the Prisonaires reveals a complex combination of accommodation and resistance. Singing in prison gave the Prisonaires a sense of identity that restored their dignity, served as a means of cultural representation, provided them with a strategy for survival, and allowed them the temporary "freedom" of regularly performing outside of the prison. But in doing so they were acting as Edwards's chief representatives in the legitimation of the penitentiary. ${ }^{27}$ Along with serving as a powerful example of Edwards's prison reform strategy, what was also communicated was that prison saved these men and made this possible. In one sense this is true: prison did make the Prisonaires possible by providing the environment wherein these five African-American men could share their lived experiences and their mutual love of close harmony singing. However, contrary to what Edwards hoped would happen, there was no post-parole career for the Prisonaires, their musical lives (as well as the media attention they received) were inextricably linked to their lives inside prison, what one might refer to as their "convictness." Because of this it could be argued that the group was the worst representation of Edwards's strategy.

For the Prisonaires and Johnny Bragg in particular, singing was the most effective,

27. This argument is most forcefully made by T.J. Jackson Lears writing about Eugene Genovese's Roll, Jordan Roll, in his essay, "The Concept of Cultural Hegemony: Problems and Possibilities," American Historical Review 90 (1985), 574-575. 
and perhaps only, strategy for survival. By the time Edwards presented them to the Nashville Exchange Club the group, in one form or another but always with Johnny Bragg singing lead, had been performing in prison for a decade under the harsh regime of Glenn Swafford. Their singing as a method of legitimating institutional discourse was the result of Edwards's keen understanding of how the image of convict/entertainers would be interpreted in the public sphere. While it is difficult to be certain what active role the Prisonaires played in this process of legitimation, one fact is certain, they were caught in the unenviable role of representing two stereotypes of African-Americans -- criminals or entertainers. And while a compelling argument can be made that life as a convict/entertainer with its temporary freedom and chance at stardom is better than simply being a convict, the Prisonaires, in spite of Edwards's best intentions, function as a kinder, gentler version of the prison work gang. Earning money for the prison as the demand for their talent increased, the Prisonaires were, to paraphrase T.J. Jackson Lears, involved in a complicated process of appropriating paternalism to create a limited set of rights for themselves. ${ }^{28}$

28. Lears, "The Concept of Cultural Hegemony," 575. 


\section{CHAPTER III: THE MAKING AND REMAKING OF MEANING}

"If I live to be 100

I guess I'll never clear my name

Everybody knows I've been in jail"

-- Merle Haggard, "Branded"

Prison as reality and metaphor hangs over the Prisonaires like a dark nimbus.

Their name, the media attention they received, even Sam Phillips's marketing strategy (e.g., records pressed with black and white striped labels), all played off of their lives as convicts. ${ }^{1}$ The group's original compositions, many of them written or co-written by Bragg, contain few, if any, overt references to prison. (The lone, notable exception being the gimmicky "A Prisoner's Prayer" written for them by James Proctor, a white Tennessee Bureau of Investigations employee.) Partly, this was the censorious reality of prison. As liberal as warden Edwards was, it's unlikely that he would have allowed the group to record songs that spoke directly to their prison experience, or were in any way critical of their environment. A fan of the Ink Spots and their superb lead singer Bill Kenny, Bragg created the Prisonaires in their likeness, and his music of romantic love, loss, and longing -- standard pop themes -- were mediated by the Penitentiary's artificially created, segregated, homosocial environment. As important, this was pop music born of a gospel tradition, a musical tradition that, in the words of Iain Chambers, provided AfricanAmericans with "a secret language of solidarity, a way of articulating oppression, a 
means of cultural resistance, a cry of hope." 2

In Rhythm and Resistance, a study of the political uses of pop music, Ray Pratt suggests that music generates a rich and complex variety of what he calls "enclaves of autonomy," spaces that create an alternative psychological reality -- a new little world within an old one. This analysis is enormously useful, but it assumes that this ongoing, complex negotiation is done within sociocultural spaces defined as free. The participants in the creation of these enclaves are connected to real social situations and organizational forms that engender and reinforce support and morale. ${ }^{3}$ For the Prisonaires, autonomy through music happened within an environment that denies freedom and severs connections to these social situations. Therefore the Prisonaires creation of an alternative psychological reality was a challenge to the dominant institution, an emancipatory use of popular culture that, as Pratt notes, is conducive to an increase in freedom and wellbeing. ${ }^{4}$ What complicates this process of resistance, empowerment, and emancipation is that, ultimately, prison mediates the results and mitigates success. No matter how many records they sold, or how often they toured, or how lauded that were as performers, in the eyes of the general public and Tennessee State Department of Corrections they were first and foremost convicts, three of them, nominally, for life. But, because their musical

2. Iain Chambers, "A Strategy For Living: Black Music and White Subcultures," in Resistance Through Ritual, eds., Stuart Hall and Tony Jefferson (London: Unwin Hyman, 1976), 162.

3. Ray Pratt, Rhythm and Resistance: The Political Uses of Pop Music (Washington, D.C.: Smithsonian Institution Press, 1990), 24.

4. Ibid., 22. 
abilities, encouraged by warden Edwards, offered them a different status as inmates, the Prisonaires were able to construct a cultural free space within a social institution wherein the ability to do so is normally restricted, constrained, and repressed.

The Prisonaires music and its function as both cultural free space and prison autobiography requires what Lawrence Levine calls and external/internal analysis. As much as the external meaning of "Just Walkin' in the Rain" is about a failed love affair, its internal meaning -- that is the meaning that reflects the lived experiences of its creators -- articulates the convict's life. Bragg remembers the song's genesis as he and co-writer Robert Riley (the non-singing "sixth" Prisonaire) were walking in the rain to their jobs in the prison laundry, "wondering what the little girls are doing." In wondering about the little girls, Bragg is acknowledging his isolation from them and, by extension, the walls that create this reality and reinforce his status as a prisoner. As much as it is a song about lost love, "Just Walkin' in the Rain" is, more tellingly, a șong about confinement, regret, and the struggle for identity. When Bragg sings "People come to windows/and they always stare at me/Shake their heads in sorrow/and say who can this fool be?" the images -- windows, sorrowful stares, and a sense of isolation and distance from others -- form an artfully constructed commentary on the "separateness" of a life lived inside prison walls. This commentary on prison life forms a strategy for survival and collective consciousness that bound the Prisonaires as inmates, musicians, and African-American men. All of this is accomplished, to quote Alan Lomax, "right under the shotguns of the guards."

5. Lawrence Levine and Alan Lomax quoted in Pratt, Rhythm and Resistance, 55. 
This use of pop music as a survival strategy and its secret language of solidarity grew from Bragg's roots in gospel music. Given that his first foray into music as a child was singing in the church, that his earliest streetcorner groups sang primarily gospel, and that the Prisonaires supplemented their original material with tried and true gospel standards (e.g., "Softly and Tenderly" and "My God is Real"), gospel's tradition of resistance through ritual was probably second nature not just to Bragg, but to the other Prisonaires as well. As with chain-gang singing and prison worksongs, gospel singing as a form of political and cultural resistance, historically, rises in opposition to forces of restriction and containment, suggesting how music can function in profoundly utopian ways. As Ray Pratt notes, - "In its creation of a new free space in a world of trouble [gospel] is also political." ${ }^{6}$ While the Prisonaires used gospel music in this manner, so too did they use pop music. By conflating the sacred and secular, the music of the Prisonaires engages in an elaborate process of signification wherein meaning is appropriated, altered, or reconstructed in relation to the dominant institution. To paraphrase Lawrence Levine, what makes these cultural components so important is that they become the creators' own, expressive of their particular worldview and lifestyles. This is not to argue that pop and gospel music did not belong to the Prisonaires prior to their incarceration, but rather that this use of pop music rooted in a gospel tradition became uniquely expressive of the Prisonaires' lifestyle and worldview as inmates, wherein the negotiation between artist and institution was ongoing. ${ }^{?}$

\footnotetext{
6. Pratt, 58-62.

7. Lawrence Levine quoted in Pratt, 66.
} 
This double commentary, the ability to convey simultaneously the emotions of a man hopelessly in love and a man in prison employs a process that Mikhail Bakhtin defines as heteroglossia, a means of expressing authorial intent in a refracted way that creates a double-voiced discourse. ${ }^{8}$ Bahktin's contention is that this discourse serves two speakers at the same time expressing two different intentions: the direct intention of the character who is speaking, and the refracted intention of the author. Most important is that within this refracted discourse there are two dialogically interrelated voices who know about one other. Adapting and applying Bahktin's theory to pop music, W.T. Lhamon refers to this use of double meaning and dialogized voices as the "codes that some apparently innocuous pop songs and other fetishized pop objects bear with them." These codes "help describe how and why disdained artists deal in doubletalk to bootleg their suppressed meanings into the public sphere."'

Any discussion of double meaning, or the articulation of resistance and empowerment in the Prisonaires' music begs an obvious and problematic question: Would this be relevant if the group was named anything other than Prisonaires? Would "Just Walkin' in the Rain" retain its encoded traces of Johnny Bragg's incarceration if his group were not convicts and were named, say, the "Freedomaires"? The simple answer is no. But as is often the case with simple answers, this one is too reductive to be useful. If

8. Mikhail Bakhtin, The Dialogic Imagination, Four Essays (Austin: University of Texas Press, 1981), 324325.

9. W.T. Lhamon, Jr., e-mail to author, May 6, 1996. Lhamon explores this idea in greater detail in his book Deliberate Speed: The Origins of a Cultural Style in the American 1950s (Washington, D.C.: Smithsonian Institution Press, 1990), 48-50. 
one listens to Johnnie Ray's chart-topping 1956 version the listener, no matter how diligent or attentive, will not make the same association with prison and incarceration. However, as was noted earlier, prison plays a complex and powerful role as a mediator in the development of an autonomous enclave, and this is also true of its role in mediating the song's message. As a cover artist with no connection to prison, Johnnie Ray has no vested interest in conveying a suppressed meaning of convict life into the public sphere, therefore one is less likely to search for a subtextual meaning about incarceration.

For Johnny Bragg, however, the situation is considerably different. Twenty-seven years old at the time "Just Walkin' in the Rain" was recorded, Bragg had spent almost half of his life behind bars and his songwriting is the result of growing up in two worlds: the relatively free world of his childhood, and the "unfree" world of adolescence and adulthood. Whether he employed this double commentary intentionally or unintentionally is not as important as is the fact that prison provides the context against which the heteroglossia becomes readable. Incarceration was as real (arguably more real) to Johnny Bragg than was freedom, and for him not to interpolate his "convictness" into his songwriting would have required extraordinary restraint and self-denial. ${ }^{10}$ Living inside what sociologist Erving Goffman defines as a total institution, the now "unfree" inmate is constantly penetrated by a sanctioning interaction from above, robbing him of the ability to create an individualized means' of balancing needs and objectives. As

10. Bragg interview, pg.46. One Bragg quote is telling, "I was educated, so to speak, in prison." 
Goffman tersely explains, "The autonomy of the act itself is violated." This constant regimentation, a ceremonialized loss of self-determination, enforces a routine that leads to, "a margin of self-selected expressive behavior -- whether of antagonism, affection or unconcern -- is one symbol of self-determination."11 In the case of Johnny Bragg and the Prisonaires, actualizing this expressive behavior in a way that was true to their lives as inmates was accomplished through singing and songwriting.

Comparing Johnnie Ray's and the Prisonaires' recordings of "Just Walkin' in the Rain" reveals stark contrasts creating a semiological shorthand that helps in decoding the compressed power of the double-voiced commentary present in the Prisonaires' version, yet seemingly absent in Ray's. Ray's 1956 version is uptempo, though not speedy, and, given the subject matter, almost inexplicably cheery. As bouncy, carefree whistling opens the song and establishes the mood, Ray's big, vibrato-heavy voice enthusiastically belts out the song's title. A strummed banjo picks up the rhythm, and at the song's bridge (i.e., "people come to windows"), male backup singers punctuate each line Ray sings with the hushed repetition of the word "walkin'." Ray's vocal gives way to a whistling solo, and the song, now cheerier than when it started, modulates into a final verse and chorus.

What is jarring about Johnnie Ray's version is how happy he sounds; almost relieved that this relationship is over. What makes his interpretive decision puzzling is that Ray had built his career on being a lachrymose ballad singer (he was known in the music business as "The Prince of Wails"), so brightening up a song perfectly suited to his

11. Erving Goffman, Asylums: Essays on the Social Situation of Mental Patients and Other Inmates (New York: Doubleday/Anchor, 1961), 38. 
histrionic style seemed counterintuitive. But Mitch Miller, the head of Columbia Records' A\&R (artists and repertoire) division, was the one who brought the Prisonaires version of the song to Ray's attention and had the most input (as was often the case with Miller) regarding the song's arrangement and production. As a result, by removing the gospel and $\mathbf{r} \& \mathbf{b}$ inflections of the Prisonaires original version emphasizes the "oldtimeyness" of Ray's version of "Just Walkin' in the Rain" emphasizes its qualities as an "old-timey" MOR (middle-of-the-road) pop song. This was not the first time, nor would it be the last, that a white artist recorded an "acceptable-for-whites" cover version of a song originally performed by an African-American artist, but a song like "Just Walkin' in the Rain" must have seemed (to both Ray and Miller) like a good fit. Better than say, Pat Boone's attempt at singing Little Richard's "Tutti Frutti."

There are two extant recordings of "Just Walkin" in the Rain" by the Prisonaires: the Sam Phillips-produced version recorded at Sun Studios June 1, 1953 that was the hit single, and a version recorded live at radio station WSIX in Nashville sometime the same year. The differences between the two recordings are minimal, but notable. Phillips, convinced that William Stewart's acoustic guitar was too thin, hired part-time session player Joe Hill Louis (for the sum of $\$ 10$ ) to add electric guitar to the recording. Bragg's lead vocal on both versions is stunning, but on the Sun recording he over-enunciates the song's first line (not surprisingly the only vocal mannerism later copied by Johnnie Ray), and his clipped, rigid, phrasing sounds forced and stagy. So much for Elvis's alleged diction lesson.

But where Johnnie Ray employs his trademark overemoting and oversinging, 
Bragg's vocal, gracefully supported by the airtight backing harmonies of the other Prisonaires, is sublime. The song's almost palpable sadness is heightened by Phillips's minimal production. The guitars of William Stewart and Joe Hill Louis are mixed low enough to provide melodic and rhythmic support, but never detract from the vocals. The tempo is slow, but not turgid, and Bragg's clear, strong voice is at its most affecting when his diction is less than precise. Unlike Ray's near bellow, there is something intimate about Bragg's conversational tone, suggesting that he has been down this road many times before. The song's climactic moment, Bragg's swooping, ethereal falsetto in the final verse, is breathtaking, a hauntingly beautiful product of the darkness within him. ${ }^{12}$

This darkness and haunting beauty is conspicuously absent from Johnnie Ray's rendition. It is too cluttered with the technical apparatuses of Mitch Miller's (over)production, becoming a fetishized commodity that is easily and readily translatable as an innocuous pop song, one that "tends toward wishful thinking, dreamy and ineffectual nostalgia, unrealistic fantasy, self-pity, and sentimental cliches masquerading as emotion."13 Very simply, as a result of production, song arrangement, and interpretive strategy, Ray's version lacks the compressed power encoded in the Prisonaires' original version. He seems unconscious of the powerful sentiment buried underneath the lyrics,

12. Colin Escott, in a 1990 interview that was excerpted for the liner essay to the CD reissue Just Walkin' in the Rain, was the first to write about the haunting quality of Bragg's singing being an expression of his inner darkness, an assertion that, I believe, reinforces the concept of Bragg's (un)conscious ability to interpolate his convictness into the Prisonaires music. Escott adds that when Bragg pronounces the word "penitentiary" it is as if he is spitting it out, something that, as Escott notes, reflects Bragg's fierce pride and his quest for dignity.

13. S.I. Hayakawa, "Popular Songs vs. the Facts of Life," Etc.: General Review of Semantics 12 (1955) 8395. In this instance Hayakawa was not speaking specifically of "Just Walkin' the in Rain," but rather the idealization of love common in American popular songs of the 1920s through 1940s. 
or simply chooses to ignore it, but in either case, this is the end result of his (and Miller's) conscious deracination of the song. By removing the plangent rhythm and blues and gospel elements of "Just Walkin' in the Rain," Ray wipes away the song's internal meaning, distancing it further from an African-American collective memory and musical tradition that emphasizes community survival, and the construction and maintenance of dignity. ${ }^{14}$ The Prisonaires, in their "strikingly dialectical way," ${ }^{15}$ explore the possibilities of the song's internal meaning by eschewing artifice for simplicity, creating a densely textured pop song that in its moments of wishful thinking, self-pity, and sentimental cliches, is subversive, empowering and, to quote W.E.B. Du Bois, realizes that even in the saddest of sorrow songs there "breathes a hope -- a faith in the ultimate justice of things." 16

14. This statement is based on the (relatively certain) assumption that Ray and Miller listened to the Prisonaires' version of the song numerous times as they worked out their arrangement. Actually hearing the song (as opposed to reading the music) would have been the best (and only) way of analyzing the similarities and dissimilarities between Bragg's and Ray's vocal styles. Since r\&b/blues inflected singing was not Ray's forte he and Miller were savvy enough to know that trying to appropriate Johnny Bragg's phrasing and vocal mannerisms would have been disastrous.

15. Eugene Genovese, Roll, Jordan, Roll: The World the Slaves Made (New York: Vintage, 1976), 324. The expression "striking dialectical way" is Genovese's description of the collective expression of attitude by slave singers, derived from Africa, but reconfigured, the result of being newly rooted in the slave experience.

16. W.E.B. Du Bois quoted by Genovese in Roll, Jordan, Roll, 249. 
In this ongoing process of resistance and cooptation pop music occupies a dual role as a means of dissident and dissonant self-expression. The use of the latter term suggests that under the constraints of social incarceration, the music of the Prisonaires, as much as it was pop music in the commonly accepted sense of ordered harmony, melody and rhythm, was also noise. Not noise in a anti-musical sense, but textual noise, noise that as Jacques Attali notes, attacks behavioral codes that constrain, analyze, mark, repress, and channel the primitive sounds of the body and its relation to self and others. ${ }^{17}$ In Noise: The Political Economy of Music, Attali describes noise as a weapon and music as the formation, domestication, and ritualization of that weapon. In other words, in order for music to be music, noise must be removed or channeled into a commodity. Not surprisingly this imposition of form and structure sounds suspiciously like the prison management system employed at the Tennessee State Penitentiary. In both instances the main objective is to create order, to remove or transform the dissonance that threatens power and dominant ideology. "Music," Attali notes, "localizes and specifies power, because it marks and regiments the rare noise that cultures. . .see fit to authorize." 18 What problematizes an understanding of "Just Walkin' in the Rain" as noise is its decided non-noisiness. In fact, were one to use the more traditional definition of noise as "a loud outcry or commotion," Johnnie Ray's version of the song would more readily

17. Jacques Attali, Noise: The Political Economy of Music, trans. Brian Massumi, Theory of History and Literature no. 16 (Minneapolis: University of Minnesota Press, 1985), 6. Because it is such a loaded term, Attali's use of the word "primitive" is problematic, as he never really defines what he means by "the primitive sounds of the body." I would suggest that in this instance the term primitive functions as a crude, unsophisticated, dissonant, pre-music, unmediated by the structures that channel noise into music.

18. Attali, 6. 
qualify. In creating a methodology of noise, Attali is concerned with dissonance and its myriad manifestations, and how music becomes a tool for the creation and consolidation of a community by linking a power center to its subjects. But can music be noise? Attali opens the door to this possibility by stating that noise exists, "only in relation to the system within which it is inscribed." Although "Just Walkin' in the Rain" is so smooth and sleek that even Sam Phillips thought it was old fashioned, it functions as noise through its potential as a critique of prison and a way of combating a debilitating life. Warden Edwards's progressivism notwithstanding, the music of the Prisonaires and its empowering ability to create a new little world within an old one, challenges the dominant institution by allowing these five African-American men their own enclave of autonomy. It may not have been enough to tear down the prison walls, but it was enough to drastically alter their lives as inmates, and provide them with limited opportunities of public expression denied to most men in similar situations. Through music the Prisonaires make noise and in doing so create a counter-narrative that contests the prison's monastic hierarchy and assumed moral superiority. No longer simply a domesticated weapon, music in the hands of men who have little else, re-channels noise, becoming in Attali's words, "the source of purpose and power."

Attali, like Ray Pratt, does not fully consider the making of noise/music from the perspective of those whose lives are defined by the total institution, an institution wherein the primary function of pop music is very different from its external role as a fetishized commodity. For him to consider this would mean problematizing what is essentially a smoothly functoining Marxist paradigm, but his analysis allows for (perhaps even 
encourages) a more expansive adaptation of his theories. "In noise," he writes, "can be read the codes of life, the relations among men." ${ }^{19}$ Certainly no one listening to the Prisonaires singing "Just Walkin' in the Rain" would leap to this association. However, Attali's point is provocative because it offers a succinct summation of how music, in the instance of the Prisonaires, mediated by the constraints of prison, turns into a subversive noise that "betokens demands for cultural autonomy, support for differences or marginality."20

19. Attali, 46.

20. Ibid., 35. 


\section{CONCLUSION}

On May 8, 1954, nearly a year after the recording session that yielded "Just Walkin' in the Rain," Sam Phillips took his portable recording equipment to the Tennessee State Penitentiary to record what would become the Prisonaires last Sun single, "What'll You Do Next," backed with "There is Love in You." A follow-up single, "Friends Call Me a Fool"/"Two Strangers" was scheduled for release in the Fall, but was never shipped. Early in 1955, the Prisonaires returned to Sun and cut three songs, "Surleen" (a Johnny Bragg composition allegedly about Jenny Price), "All Alone and Lonely," and "Rockin' Horse." With these songs the smooth, close harmony of "Just Walkin in the Rain" had been replaced by a harder, more aggressive rhythm and blues style. None of the songs were released until 1991.

By 1955 the group was breaking up. John Drue and Marcel Sanders, the two Prisonaires serving the shortest sentences, had been paroled; William Stewart and Ed Thurman soon followed. ${ }^{1}$ Johnny Bragg, still an inmate, formed a new groups called the Marigolds. "The Marigolds had a different sound," Bragg explains. "We did less gospel, more country, some pop ... the Marigolds was mostly an update of the Prisonaires." ${ }^{2}$ As

1. Escott, Just Walkin' in the Rain, 18. Escott notes that Thurman's parole was controversial and was met with negative press. He cites an editorial in the April 25, 1955 Nashville Tennessean that stated: "The people of Tennessee can only hope that the killers still behind bars are non singers."

2. Bragg interview, 63 . 
for the paroled Prisonaires they all died, "in varying degrees of poverty or distress." Only Robert Riley, Bragg's non-singing songwriting partner, managed to make a modest living as a contract songwriter for Nashville-based record labels Dial, Todd, and Sound Stage Seven. James Edwards is retired and lives in Murfreesboro, Tennessee. He left his position as warden of the Tennessee State Penitentiary in 1956 to take a job working in industrial relations, a career move that was, as he tells it, considerably less stressful and more lucrative than that of running the state's largest prison.

As for Johnny Bragg he, unlike many African-American songwriters in the 50s, received most of his songwriting royalties that came as a result of Johnnie Ray's millionselling version of "Just Walkin' in the Rain'" He was released from prison in 1959 and began recording and writing songs for Decca Records in Nashville, but was returned to prison in 1960 for robbery and attempted rape. ${ }^{3}$ In 1967, Bragg was released and started Elbejay Records with Raymond Ligon and Cyril Jackson, where he recorded mostly country songs until the mid-1970s. Today, Bragg still lives in Nashville working, as he puts it, as a full-time "family man" spending as much time as he can with his daughter and grandson. His fondest career memory remains his time with the Prisonaires: "I'm very proud of them [the Prisonaires] and I miss that, they're all gone now, that's

3. Bragg interview, 20. Bragg's version of the events leading up to his second arrest are as follows: "Well, this particular time when they [the police] arrested me I was chasing a woman in a car. 'Johnny Bragg was chasing a white woman to rape her.' Later it came out that the woman had hit [my] car and [I] wanted to talk to the woman. Well, when they found out that they had Johnny Bragg out there -- see, they were killing black people in them days -- so when it was [me] they said, 'Lets kill him'. I know one of the guys names .. .me and him became friends after that ... he said, 'Johnny, we done you wrong, the damn woman hit your car, you weren't trying to rape that woman, but we made it look that way, and we was wrong.'" Bragg was charged with attempted rape and robbery. He was convicted of the robbery charge (theft of $\$ 2.50$ from the woman in question) and returned to prison. 
something you can't forget." ${ }^{4}$ And although he doesn't make records any more, nor shows any interest in doing so, every so often Johnny Bragg attends services at his neighborhood church and sings.

$$
* \quad * \quad * \quad *
$$

In the Souls of Black Folks, W.E.B. Du Bois refers to the beauty of spiritual singing as "the music of an unhappy people, of the children of disappointment." ${ }^{5}$ In 1990 Johnny Bragg told Colin Escott that his troubles "started when I was 12 years old." As a man-child isolated from the Promised Land for nearly three decades, Johnny Bragg's evocative songs articulate the sadness of the children of disappointment. The music he made with the Prisonaires, for all of its triumphs, is ultimately the music of unhappy people -- men caught in a paradoxical search for personal freedom while fully cognizant of a future consigned to prison. That they achieved fame as a novelty act and were finished as a group little more than year after their first recording session has forever confined the Prisonaires to the margins of rock and roll history. But their brief career and the circumstances under which it flourished articulates what it means to create music in a hostile, controlled environment and the double-voiced messages that emerge when music is mediated by a total institution. Despite being overlooked and misunderstood there is an unescapable passion, dignity, and ultimately, freedom to the story of the Prisonaires that can be heard if one takes the time to go walking in the rain.

4. Ibid., 68.

5. W.E.B. Du Bois, The Souls of Black Folks (New York: Bantam, 1989), 179. 


\section{BIBLIOGRAPHY}

Attali, Jacques. Noise: The Political Economy of Music. Minneapolis: University of Minnesota Press, 1985.

Bakhtin, Mikhail. The Dialogic Imagination, Four Essays. Austin, TX: University of Texas Press, 1981.

Chambers, Iain. "A Strategy For Living: Black Music and White Subcultures," in Resistance Through Ritual, eds. Stuart Hall and Tony Jefferson. London:Unwin Hyman, 1976.

Doyle, Don. Nashville in the New South 1880-1930. Knoxville: University of Tennessee Press, 1985. . Nashville Since the 1920s. Knoxville: University of Tennessee Press, 1985.

Du Bois, W.E.B. The Souls of Black Folks. New York: Bantam, 1989.

Escott, Colin. "Just Walkin' in the Rain." Bear Family BCD 15523, compact disc booklet essay, 1991. , and Martin Hawkins. Good Rockin' Tonight: Sun Records and the Birth of Rock'n'Roll. New York: St. Martin's Press, 1991.

Foucault, Michel. Discipline and Punish: The Birth of the Prison. New York: Vantage, 1979.

Franklin, H. Bruce. The Victim as Criminal and Artist. New York: Oxford University Press, 1978.

Genovese, Eugene. Roll, Jordan, Roll: The World the Slaves Made. New York: Vintage, 1976.

Goffman, Erving. Asylums: Essays on the Social Institution of Mental Patients and Other Inmates. New York: Doubleday/Anchor, 1961.

Green, Fletcher Melvin. "Some Aspects of the Convict Lease System in the Southern States," in Democracy in the Old South, ed. J. Issac Copeland. Nashville: Vanderbilt University Press, 1969.

Guralnick, Peter. Last Train to Memphis: The Rise of Elvis Presley. New York: Little Brown, 1994. 
Hayakawa, S.I. "Popular Songs vs. the Facts of Life," General Review of Semantics 12 (1955).

Lears, T.J. Jackson. "The Concept of Cultural Hegemony: Problems and Possibilities," American Historical Review 90, 1985.

Lhamon, W.T., Jr. Deliberate Speed: The Making of a Cultural Style in the American 1950s. Washington, D.C.: Smithsonian Institution Press, 1990.

McKelvey, Blake. American Prisons, 3d ed. Montclair, NJ: Greenwood, 1968.

Pratt, Ray. Rhythm and Resistance: The Political Uses of American Popular Music. Washington, D.C.: Smithsonian Institution Press, 1990.

Shelden, Randall. "From Slave to Caste Society: Penal Changes in Tennessee, 18301915," Tennessee Historical Quarterly 38, (1990).

\section{NEWSPAPERS}

Nashville Banner. 17 June, 18 March 1953.

Nashville Tennesean. 11 January 1953.

\section{INTERVIEWS}

Bragg, Johnny. Interview by Barry Alphonso and Don Hildebrand, 25 September 1996. Transcript, Cassell Productions, Thousand Oaks, CA.

Edwards, James. Interview with author. 18 May 1996. 


\section{JOHN DOUGAN}

Born in Worcester, Massachusetts (birthplace of Samuel Fuller, Abbie Hoffman, and Mark "The Bird" Fidrych), December 23, 1954. Interrupted academic career in 1976 to write music criticism and play drums in a rock and roll band. A two year stint at the Springfield, MA Daily News led to a freelance career of over 15 years with work published in Spin, Rolling Stone, In These Times, Utne Reader, City Pages, Option, Rock and Roll Disc, CD Review and, most recently, the All Music Guide to Rock, All Music Guide to Country, and All Music Guide to the Blues. Received BA in English from Westfield (MA) State College in 1994. Entered the graduate program in American Studies at the College of William and Mary in 1995. 